\title{
Identifying Misalignments between Public Participation Process and Context in Urban Development
}

\author{
Matthew Cohen ${ }^{1}$ and Arnim Wiek ${ }^{2}$ \\ ${ }^{1}$ Department of Earth and Environmental Sciences, Furman University, Greenville, SC, USA \\ ${ }^{2}$ School of Sustainability, Arizona State University, Tempe, AZ, USA \\ * Corresponding author: E-Mail: matthew.cohen@furman.edu; Tel.: +1 8642942505
}

Submitted: 12 March 2017 | In revised form: 22 June 2017 | Accepted: 12 July 2017 |

Published: 25 August 2017

\begin{abstract}
Public participation is a common element in state-of-the-art urban development projects. Tailoring the public participation process to the local context is a popular strategy for ensuring sufficient turnout and meaningful engagement, but this strategy faces several challenges. Through a review of case studies of public participation in urban development projects, we identify ten typical misalignments between the public participation process and the local context, including the lack of policy maker support, adverse personal circumstances of participants, low collaborative capacity, and mistrust, among others. When a public participation process is not aligned to the local context, the process may generate outcomes that compromise public interests, inequitably distribute benefits among stakeholders, or favor powerful private interests. This study offers caution and guidance to planning practitioners and researchers on how to contextualize public participation in urban development projects through the categorization of common misalignments that ought to be avoided.
\end{abstract}

Keywords: Local governance; public participation; stakeholder engagement; sustainability governance; urban development

\section{Introduction}

Once a top-down process, over the past four decades governance has shifted to the local level, and there towards civic engagement and the democratization of policy making [1-3]. Civil society now plays a larger role in setting priorities for and contributing to local community development, environmental management, transportation, health, and public safety issues $[4,5]$. Highlighting its general acceptance in society, public participation has become a rhetorical feature of good local governance and sustainability governance [3,6-9].

Urban development is one prominent arena for local governance efforts. Following the general trend, public participation is now a common feature of urban development projects [10-13], in particular when they aim at fostering urban sustainability $[14,15]$. Its rise in urban development in general, and urban sustainability efforts in particular, is due to a number of benefits public participation is assumed to offer.

Supportive perspectives contend that public participation builds trust between participants and experts [16], and between the public and decision makers [5]; facilitates conflict resolution [17]; establishes support for implementation $[18,19]$; creates equitable processes, which in turn produce just outcomes [20]; fosters social learning and builds capacity in individuals as well as across society [21-23]; engages 
stakeholders with diverse perspectives that collaborate to understand and solve complex societal problems [24,25]; develops social capital through the formulation of social networks [23,26]; and builds institutional capacity [26]. As such, there are many case studies that describe public participation as a beneficial process [18,27-29].

While there are numerous arguments in favor of participation, other researchers and practitioners caution that there are also challenges to and adverse effects from public participation: governments are often overly dominant in public participation processes [26,30], or lack capacity to conduct such processes [4]; civil society's civic capacity is declining, and many citizens now lack competencies needed to participate $[4,31]$; citizens often do not have the time to meaningfully engage [26], or are apathetic and not interested in participating [32,33], while others distrust participation as a process that bends to manipulative sponsors and powerful elites [34]; and resources to participate are not equally distributed to disadvantaged groups [26], among other challenges. As a result, public participation processes are often formulaic [35], susceptible to cooptation [31], or can even be coercive [36].

Many pitfalls can be mitigated and avoided through careful process design $[37,38]$, and one popular recommendation is to design processes to fit the local context [7,37-40]. Yet, little specific directives are provided for how such contextualization might be achieved.

Here, the concept of local context in public planning may include considerations of local priorities and issues specific to locations across geographic settings, from local [7] to regional and national-scales [37]. Working within and across spatial scales, one must consider contextual factors including local knowledge of participants; public preferences; types of interested stakeholders; local conditions; the environmental context; laws guiding public decision and policy making; local and national interests; social relationships within communities [37]; cultural norms of decision making; race, class, and gender; environmental problems and their significance; and political stability [40].

Dietz and Stern [37] identify numerous contextual factors for public participation processes in environmental decision making, and they organize these factors into two categories: (1) Agency Factors and (2) Participant Factors. Von Korff et al. [38] list contextual factors that include conflict between stakeholders, participants' previous experiences in public processes, legal and regulatory rules, budgets, and stakeholder interest (or apathy). Bryson et al. [39] define both a general and a specific context. They explain the general context as the "social, demographic, political, technological, physical, and other features and trends in an organization's environment (p. 25)". The spe- cific context, they note, includes "stakeholders, applicable mandates, [and] resource availability (p. 25)". All of these issues may be influenced by and specific to the location where a participatory process is being designed and/or carried out.

Urban development is generally guided by planning processes that include opportunities for varying degrees of public involvement on topics such as transportation, land use, infrastructure, housing, economic development, and environmental management. Yet, public participation may not be fruitful if the process is not well aligned to the local context. The objective of this research is to better understand the local context of urban development projects by asking what categorizable impediments to high quality public participation arise when the participatory process is not attuned to the local context.

The research presented in this paper studies peerreviewed articles that report on public participation processes in urban development projects. The research catalogues common challenges that are reported in the literature, and the analysis categorizes these challenges into generic cases of when public participation processes may be misaligned with their local context. This study's intent is to caution and guide planning practitioners and researchers on how to contextualize public participation in urban development projects through the categorization of misalignments that ought to be avoided.

\section{Conceptualizing Public Participation}

Public participation is often vaguely defined in the literature, while in actuality it can take many shapes and forms. Dietz and Stern [37] acknowledge that public participation may encompass all facets of democracy, including voting, expressing opinion, interest groups, demonstrations, and even songs. Thus, we first present the concept of public participation we adopt in this study, which is based on a proposal made by Wiek et al. [41].

The concept composes three key features of public participation (Figure 1), dealing with the questions of who is doing what, with whom, when, for what purpose, and with what outcome [42]. First, public participation as conceptualized here is part of and therefore depends on an 'official' urban development project, in which the public participates. We focus here on participation that occurs in 'officialized spaces' and is part of regulated procedures [43]. The urban development project, as the main process, is structured into various phases (e.g., preparing, planning, implementing, and evaluating), with each phase generating certain outcomes, including a proposal, a plan, real-world changes, and recommendations. 


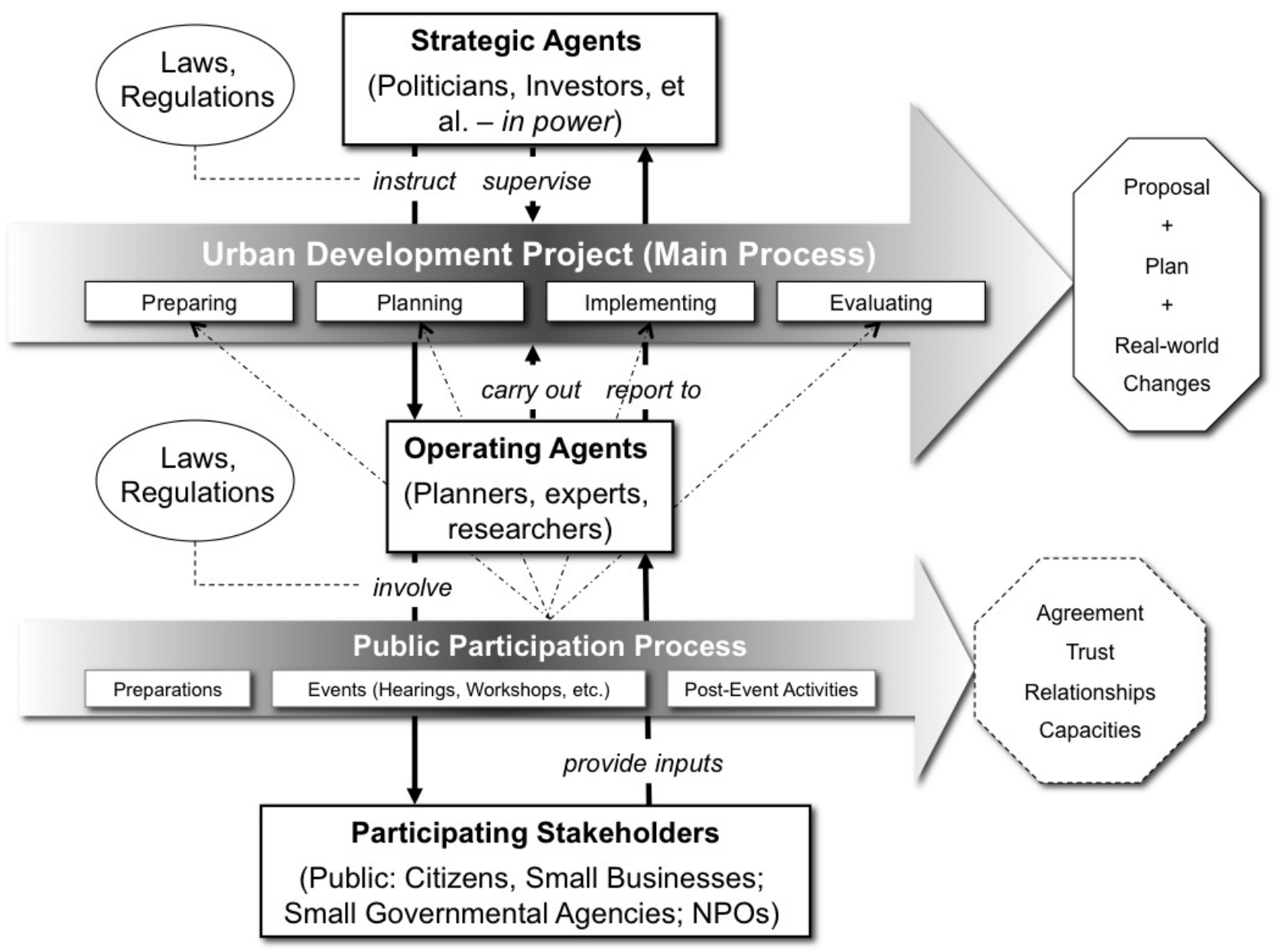

Figure 1. Key features of public participation in urban development projects (adapted from [41]).

Second, the urban development project is supervised by Strategic Agents such as elected officials and investors (applying and/or influencing laws and regulations), and is carried out through Operating Agents such as planners and experts (who report back to the Strategic Agents). The Operating Agents engage stakeholders through the public participation process; stakeholders might include citizens, residents, non-profit organizations, businesses, governmental agencies (not supervising), and the media.

Third, through the public participation process the public might participate in one, several, or all phases of the urban development project, and to varying degrees. The public participation process may rely on different standardized procedures, such as public meetings, citizen juries, focus groups, stakeholder workshops, consensus conferences, and web-based engagements, among others [44]. Apart from substantive inputs that might inform, to varying degrees, the outcomes of the phases as indicated above-the public participation process can also yield less tangible outcomes such as agreement, trust, new or strengthened relationships, and enhanced capacities [23].

Even within the parameters used in this study to define public participation, there is a wide spectrum of processes ranging in levels of participant engagement. For decades, planning literature has addressed this issue. Arnstein [1] presented a framework for interpreting degrees of citizen power in local decision making, ranging from manipulative processes, to tokenistic engagements like public hearings, to instances of delegated power and true citizen control. In the years following, many scholars further studied, revised, and built upon Arnstein's concept to define public participation as an engaged and empowered mechanism for the public [for examples, see $[7,16,26,37,45,46]$.

Today, there is much support in the literature for public participation processes to be popular, deliberative mechanisms for shaping public policy. For instance, Voogd and Woltjer [47] present five ethical criteria for what they term communicative planning: (1) involve all relevant stakeholders in the planning process, (2) prevent cultural and educational differences from hindering stakeholders, (3) design manageable and transparent planning processes, (4) provide participating stakeholders with necessary professional knowledge, and (5) prioritize the interests of stakeholders in defining and weighting solutions. Fung and Wright [27] idealize empowered deliberative democracy (EDD), which pursues participatory and deliberative governance by (1) 
devolving power to local stakeholders, (2) centrally managing participation through governmental structures, and (3) institutionalizing participation within government. Abelson et al. [48] evaluate deliberative processes in terms of (1) representation of stakeholders; (2) legitimacy, reasonableness, and responsiveness of procedures; (3) sharing, presentation, and interpretation of information; and (4) outcomes in terms of legitimacy and accountability, participant satisfaction, and level of consensus.

All of these conceptualizations of public participation define a decision-making process that engages diverse stakeholders through deliberative procedures to shape policy. In this article, we focus on how the public participation process is designed by planners and other Operating Agents, considering the features just described. When aligning the process to the local context, planners need to consider the interplay between issue, public agency, and participant $[37,49]$, as well as conflicts between stakeholders, participants' previous experiences in civic engagement, legal and regulatory settings, budgets, and stakeholder interest and apathy [38]. Furthermore, factors including cultural norms, race, socio-economic status, gender, the salience of issues, and the political climate also contribute to how well a participatory process fits within the local context [40].

\section{Methods}

This study inspects the common challenges to realizing the ideals of public participation with the assumption that considering such challenges at the outset will help project planners understand the local context of where a participatory process is designed and implemented. Through exploratory research, we inductively defined misalignments between the public participation process and local context by (1) reviewing case studies from peer-reviewed literature on public participation in urban development projects, (2) recording challenges identified in the cases, and (3) grouping the identified challenges into overarching categories. We then conceptualize these challenge categories as misalignments between the process (as designed by planners and experts) and the local context.

To select case studies for review we used the following search terms: case study AND public participation; public participation AND urban development; public participation AND urban planning; and challenge AND public participation. We considered only resources published since 1995.

To filter the search results, we created a small set of selection criteria. First, this study seeks to learn from real cases of public participation in urban development projects. Therefore, we eliminated pieces that were strictly theoretical or that spoke in generalities without referencing specific cases. Second, this study is only concerned with public participation in urban development projects. Thus, we eliminated materials that discussed participation in contexts other than urban development settings. Third, we review only cases from the Global North. It is already challenging to compare experiences between such dissimilar cultures as northern Europe and the United States, and we chose to eliminate cases from developing countries that have much different development needs and conditions that further confound cross-context comparisons. Finally, this study synthesizes common challenges reported in the literature, and therefore considers only case studies that acknowledge real challenges that have arisen in public participation processes. After narrowing the case pool further, we consulted the reference sections of the relevant sources to uncover additional empirical studies that did not show up through the Boolean search. These methods yielded 24 cases. Table 1 lists and describes the cases studied for this research.

We approached this review with a heuristic developed in urban development projects with public participation we have been involved in over a five-year period in low-income neighborhoods in Phoenix, Arizona (2009-2014). Challenges we encountered include lack of collaborative capacity, civic competence, and sustainability literacy, as well as living conditions and personal circumstances not conducive to continuous and meaningful public engagement [41]. As we reviewed case study literature on public participation in urban development, we recorded when a case provided an example of one of the misalignments we had ourselves experienced in past public participation projects. We also recorded when cases articulated a challenge that we had not previously considered. After reviewing all of the cases, we reviewed our draft list of challenges in public participation processes and created a list of potential misalignments.

As noted above, we recognize the challenge of drawing conclusions across disparate settings. For this reason, we excluded studies from the Global South, but we still must confront the difficulties of conducting an analysis of cases in settings ranging from the United States to Northern Europe to Australia. In each of these locations historical norms, governance regimes, and the local environment, among other factors, play a significant role in shaping the models of public engagements that are pursued and impact the way that participation plays out. To cope with the array of cases across multiple diverse contexts, we required that a potential misalignment must be found in at least three of the articles we reviewed. Capturing examples from multiple settings allowed us to draw careful conclusions generalized across dissimilar contexts. Furthermore, this consideration allowed for some quality control as the analysis is entirely dependent on the research of other scholars. 
Table 1. Case studies from the literature for misalignment analysis.

\begin{tabular}{lllc}
\hline & \multicolumn{1}{c}{ City } & \multicolumn{1}{c}{ Project Details } & Source \\
\hline 1 & New York, U.S. & Citizen advisory committees in environmental planning & {$[50]$} \\
2 & Northeast Ohio, U.S. & Survey of participants of public processes in three cities & {$[49]$} \\
3 & Ontario, Canada & Public roundtables addressing environmental degradation & {$[51]$} \\
4 & Atlanta, U.S. & Public housing revitalization project & {$[52]$} \\
5 & Chicago, U.S. & Empowered participatory school management & {$[27]$} \\
6 & Unidentified city, Australia & Aboriginal arts and economic development program & {$[53]$} \\
7 & London, England & Economic development initiative in Hackney & {$[54]$} \\
8 & Two unidentified cities, England & Public participation initiatives in two English cities & {$[55]$} \\
9 & Omaha, U.S. & Participatory watershed planning & {$[56]$} \\
10 & Sydney, Australia & Community participation in transportation planning & {$[57]$} \\
11 & Waterloo, Canada & Participatory visioning project & {$[58]$} \\
12 & Waterloo, Canada & Public participation for local transportation planning & {$[59]$} \\
13 & Helsinki, Finland & Participatory process for urban forestry planning & {$[21]$} \\
14 & Multiple cities, U.S. & Survey of public administrators & {$[60]$} \\
15 & Unidentified city, England & Public involvement for Local Agenda 21 & {$[34]$} \\
16 & Minneapolis, U.S. & Neighborhood revitalization program & {$[18]$} \\
17 & Multiple cities, Europe & Public participation in urban forestry & {$[61]$} \\
18 & San Diego, U.S. & Environmental conservation for coastal development & {$[62]$} \\
19 & Ottawa, Canada & Participatory evaluation of supportive housing & {$[63]$} \\
20 & Vancouver, Canada & Public process for creating sustainability indicators & {$[64]$} \\
21 & Vancouver, Canada & Climate change visioning and scenario building & {$[65]$} \\
22 & Tampere, Finland & Participatory process for city transportation plan & {$[66]$} \\
23 & South Dunedin, New Zealand & Attempt to include low income community in decision making & {$[67]$} \\
24 & Chicago, U.S. & Participatory process for mixed-income housing development & {$[31]$} \\
\hline & & &
\end{tabular}

\section{Results and Discussion: Misalignments between Public Participation Process and Local Context}

The literature review resulted in ten misalignments. These misalignments are organized into three categories within the participatory process. These three categories were derived inductively through the literature reviewed for this study. Misalignments that Impede Process and Outcomes pertains to top-down issues of whether policy makers and special interests support public participation processes, divest power to diverse stakeholders, and allow public input to shape policy. There is one misalignment under this category.

Misalignments that Impede Participants' Attendance considers the structural and systemic barriers to participation that certain communities experience. When these misalignments transpire, participation events may feature low participant turnout, and particular groups may not be included in the process. This category includes three misalignments.

Misalignments that Impede Participants' Input covers barriers experienced by participants that do attend events. These may include the values, preferences, and capacities of participants. When these misalignments arise, participants may refrain from full participation, they may feel unheard, or they may even obstruct the process (though it is important to consider that dissent within a deliberative process may actually be constructive [68]). There are six misalignments reported for this category.

All ten misalignments present unique impediments to conducting a high quality public participation process. Identifying, analyzing, and planning to mitigate these misalignments presents a framework for understanding the local context within which the public participation process and greater urban development project take place. Table 2 presents the misalignments.

\subsection{Misalignments that Impede Process and Outcomes}

Top-down, institutional support is a critical factor for successful participation [69,70], and public administrators' confidence in the public strongly influences citizen involvement in policy making [60]. When the public participation process does not align with policy-maker support, it may be that decision makers are not willing to divest authority to the public or special interests hold more power than participating stakeholders. When this occurs, policy outcomes may not reflect participant recommendations, bringing into question whether the political impact equals the effort devoted by participants and the resources invested by process planners [71]. Leino and Laine [66] describe a participatory process to develop the traffic master plan for Tampere in Finland. A group of stakeholders, recruited by the city, con- 
vened to provide input to the plan. Participants felt, however, that they did not have sufficient influence through this process. Instead, they collaboratively wrote two position papers about the traffic plan and provided these as input. Decision makers did not consider the participants' input, and the final plan did not reflect the participants' preferences. In this case, the process broke down and participants lost faith in government, choosing to operate outside of the official process. Ultimately stakeholders received no return on the time they invested, and the city wasted resources holding a process that did not inform the final plan.

\subsection{Misalignments that Impede Participant Attendance}

\subsubsection{Misalignment between the Public Participation Process and Participants' Personal Circumstances and Living Conditions}

When the public participation process does not align with participants' personal circumstances and living conditions, planners and experts are not sensitive to the impact that stakeholders' lifestyles have on their ability and willingness to participate. Some obstacles to participating may include individuals working multiple jobs, caring for children, and lacking transportation, among others. When participation is not attuned to personal circumstances and living conditions of prospective participants, then events may be poorly attended or traditionally underrepresented groups (low-income individuals, minorities, women, youth) may be excluded. Through a study of the Minneapolis Neighborhood Revitalization Program (NRP) in Minnesota, United States, Fagotto and Fung [18] identify certain groups that participate less, specifically communities of lower socioeconomic status. In these communities, resources like wealth, education, status, and time are not equally distributed and a lack of these resources presents a barrier to participation. The NRP, an empowered governance program for neighborhood improvement, demanded skill, time, and background knowledge, making it hard for some populations to participate. These challenges, among others established a process that favored homeowners, while in many neighborhoods renters and minorities did not sufficiently influence decision making.

\subsubsection{Misalignment between the Public Participation Process and Community Civic Engagement}

The level of civic engagement that is present in a community may influence the public's capacity and interest in participating in urban development projects. Putnam [72] describes the general decline of civic engagement in the United States, including a reduction in political, civic, and religious participation; volunteering and philanthropy; social engagement in the workplace; unionization; and social interaction. Through interviews and focus group discussions with citizens and public administrators in northeast Ohio, United States, King et al. [49] learned from respondents that the decline of neighborhoods as social organizations was leading communities to become less civically engaged. As these neighborhoods lose a culture of community, they are experiencing social isolation and a decline in civic participation.

There are also cases in which the public wishes to provide input, but process designers fail to engage stakeholders through means that are relevant to the context. In a mixed-income housing project in Chicago, professionals wished to engage relocated public housing residents through neighborhood association mechanisms that were commonly used to communicate with higher income neighborhood residents. The neighborhood association mechanism was not relevant to the relocated public housing residents because the associations were oriented towards homeownership and institutional interests with which public housing residents did not relate. Low-income renters had traditionally participated in Local Advisory Councils (LACs), which were common in public housing developments. LACs were disbanded in favor of neighborhood associations, and low-income residents lost their outlet for participation. Professional stakeholders (developers, property managers, etc.) thought it would be beneficial to integrate relocated public housing residents into mainstream associations, but the low-income residents instead felt disempowered. Because the government and professional actors would not engage with relocated public housing residents through mechanisms with which the population was comfortable, the interests of developers, institutional actors, and homeowners outweighed the needs of lowincome residents [31].

\subsubsection{Misalignment between the Public Participation Process and Participants' Trust}

Bad experiences with previous engagements, disempowerment, and general lack of trust in government are some contributing factors to low participant trust. When the public participation process does not align with participants' trust, individuals may choose to not participate, or those that do attend events may -[20]withhold input or be obstructionist. Eversole [53] describes a community consultation process for an aboriginal arts and economic development program in Australia. The process was managed by consultants seeking to empower urban aboriginal communities. The consultants did not communicate public meetings through the appropriate community channels, leading the consultants to be perceived as outsiders. This poor communication coupled with negative experiences from past participatory engagements led community members to distrust the process and to not participate. It is important to note that bad experiences in prior engagements compromised recruitment of participants for this case. Likewise, a poorly executed participation process today may compromise the success of future projects. 
Table 2. Misalignments between public participation process and local context.

\begin{tabular}{|c|c|c|c|c|}
\hline Impediments to & $\begin{array}{l}\text { The public } \\
\text { participation process } \\
\text { does not align with }\end{array}$ & Description & Example & Case Studies \\
\hline $\begin{array}{l}\text { Process and } \\
\text { outcomes }\end{array}$ & Policy maker support & $\begin{array}{l}\text { The level of decision-making } \\
\text { power public authorities are } \\
\text { willing to divest to the public }\end{array}$ & $\begin{array}{l}\text { Participants draft white papers but } \\
\text { documents do not influence } \\
\text { decision makers [66] }\end{array}$ & $\begin{array}{l}{[34,49,50,54,56-} \\
62,66,67]\end{array}$ \\
\hline \multirow[t]{3}{*}{$\begin{array}{l}\text { Participant } \\
\text { attendance }\end{array}$} & $\begin{array}{l}\text { Participants' personal } \\
\text { circumstances and } \\
\text { living conditions }\end{array}$ & $\begin{array}{l}\text { The impact of stakeholders' } \\
\text { lifestyles on their ability and } \\
\text { willingness to engage }\end{array}$ & $\begin{array}{l}\text { Certain groups identify barriers to } \\
\text { participation, including lack of } \\
\text { resources like wealth, education, } \\
\text { status, and time [18] }\end{array}$ & {$[18,31,49,54,59]$} \\
\hline & $\begin{array}{l}\text { Community civic } \\
\text { engagement }\end{array}$ & $\begin{array}{l}\text { The level of engagement } \\
\text { already existing within a } \\
\text { community }\end{array}$ & $\begin{array}{l}\text { Respondents identify the decline } \\
\text { of neighborhoods as a social } \\
\text { organization as reason for } \\
\text { communities becoming less } \\
\text { civically engaged [49] }\end{array}$ & {$[31,49,54]$} \\
\hline & Participants' trust & $\begin{array}{l}\text { Participants' buy-in of the } \\
\text { participatory process }\end{array}$ & $\begin{array}{l}\text { Prospective participants do not } \\
\text { trust the process and are hesitant } \\
\text { due to experiences from past } \\
\text { engagements [53] }\end{array}$ & {$[31,53,58,64]$} \\
\hline \multirow[t]{6}{*}{ Participant input } & $\begin{array}{l}\text { Participants' } \\
\text { engagement } \\
\text { preferences }\end{array}$ & $\begin{array}{l}\text { The input participants may } \\
\text { provide in how they wish to } \\
\text { engage }\end{array}$ & $\begin{array}{l}\text { Participants prefer more intensive } \\
\text { engagements with personal } \\
\text { interactions; public officials } \\
\text { prioritize other practices [66] }\end{array}$ & {$[21,31,49,54,55,66]$} \\
\hline & $\begin{array}{l}\text { Participants' } \\
\text { expectations }\end{array}$ & $\begin{array}{l}\text { Participants' anticipated policy } \\
\text { outcomes }\end{array}$ & $\begin{array}{l}\text { Throughout the engagement } \\
\text { process, participants do not see } \\
\text { direct outcomes from participation } \\
\text { [59] }\end{array}$ & {$[21,55,59,64]$} \\
\hline & $\begin{array}{l}\text { Participants' civic } \\
\text { competence }\end{array}$ & $\begin{array}{l}\text { Participant understanding of } \\
\text { local political processes }\end{array}$ & $\begin{array}{l}\text { Tenants in a public housing } \\
\text { revitalization program submit a } \\
\text { project proposal but did not } \\
\text { participate in the revision process } \\
\text { because they thought the process } \\
\text { had already concluded [52] }\end{array}$ & {$[52,54,64,66]$} \\
\hline & $\begin{array}{l}\text { Participants' } \\
\text { collaborative capacity }\end{array}$ & $\begin{array}{l}\text { The ability of stakeholders to } \\
\text { meaningfully participate in a } \\
\text { facilitated group activity }\end{array}$ & $\begin{array}{l}\text { Citizens admit community } \\
\text { members do not have the capacity } \\
\text { to participate in decision making } \\
\text { and that they have been granted } \\
\text { too much power too soon [54] }\end{array}$ & {$[21,27,31,54,63,67]$} \\
\hline & $\begin{array}{l}\text { Participants' } \\
\text { sustainability literacy }\end{array}$ & $\begin{array}{l}\text { The gap in knowledge and } \\
\text { attitudes about sustainability } \\
\text { between experts and } \\
\text { stakeholders }\end{array}$ & $\begin{array}{l}\text { Participants tasked with identifying } \\
\text { sustainability indicators admit to } \\
\text { being unfamiliar with sustainability } \\
\text { principles, requiring substantial } \\
\text { capacity building [64] }\end{array}$ & {$[50,64,65]$} \\
\hline & $\begin{array}{l}\text { Participants' issue } \\
\text { competence }\end{array}$ & $\begin{array}{l}\text { Participant's lack of } \\
\text { knowledge about urban } \\
\text { development issues, } \\
\text { principles, processes }\end{array}$ & $\begin{array}{l}\text { Participants require capacity } \\
\text { building on issues including crime, } \\
\text { education, housing, and health to } \\
\text { produce relevant statistics [54] }\end{array}$ & {$[18,54,61]$} \\
\hline
\end{tabular}




\subsection{Misalignments that Impede Participant Input}

\subsubsection{Misalignment between the Public Participation Process and Participants' Engagement Preferences}

When the public participation process does not align with participants' engagement preferences, process designers may have failed to seek or incorporate stakeholder input for engagement structure and have not considered whether prospective participants have preferences for how they might engage. When this happens, stakeholders may be uncomfortable participating or dissatisfied with the process, leading to a lack of acceptance, diminishing trust, and declining attendance at events. In a case study of urban forestry planning in Helsinki, Finland, authorities were concerned with the cost of intensive participation. Although the participatory system employed was considered extensive, residents still felt that the process lacked sufficient opportunities for participation. While the public showed preferences for small group meetings and similar methods, planning authorities preferred to use surveys for data collection. The authors conclude that no single method is perfect for all situations and several methods should be employed throughout a participatory process [21].

\subsubsection{Misalignment between the Public Participation Process and Participants' Expectations}

In many cases, experts and planners have different goals and expectations than the public, with participants often reporting to prefer greater levels of engagement than planners typically provide [73]. To accept the legitimacy of public participation, stakeholders need to see the efficacy of their participation. When the public participation process does not align with participants' expectations, process designers may worry about losing participant buy-in for the immediate engagement and losing public trust over the long term. In public transportation planning processes in Warrington Borough and Warwickshire County, England, participants expected their input to directly influence the resulting transportation plan. Instead, they found the process to lack transparency and could not explicitly see how their input was included in process outputs. After the process, participants were left confused and frustrated [59].

\subsubsection{Misalignment between the Public Participation Process and Participants' Civic Competence}

Not all members of the public fully understand local political processes. When the public participation process does not align with participants' civic competence, process designers may not have appropriately articulated the purpose of the engagements, how engagements will fit into the greater decision-making process, and how participant input will be used. When this occurs, the process and its outcomes may fail to meet participant expectations, leading to an erosion of trust. Also, when navigating the participation process requires certain competency levels, participants may be filtered out of decision making [74]. Poindexter [52] describes a public housing revitalization process in Atlanta, United States in which tenants negotiated and ratified a project proposal. Participants thought that they had concluded the participatory process and that their proposal would be accepted. Instead, authorities saw this point as the beginning of the planning process and revised citizen input with little additional consultation. Because the tenants did not understand the full policy-making procedures, they failed to engage during a critical point in the process and the policy outcome favored developers' rather than the residents' interests.

\subsubsection{Misalignment between the Public Participation Process and Participants' Collaborative Capacity}

Meaningful participation in a facilitated group activity requires skill. Participants may need to speak publicly, listen actively, balance diverse and contrasting perspectives, weigh tradeoffs, and seek compromise. When the public participation process does not align with participants' collaborative capacity, then engagement activities may not have been designed with varying public capacities in mind. When this misalignment persists, participants that are better prepared to participate may have disproportionate influence. When a group of participants struggles to listen to each other and share their perspectives constructively, a negative dynamic may obstruct the generation of ideas. In a public planning process for economic development in the London Borough of Hackney, policy makers sought to engage members of the population that were traditionally excluded from decision making. Through the process, citizens admitted that members of their community lacked the capacity to participate and that they had been given too much power too soon. Anger arose amongst participants because they felt empowerment and capacity building was poorly executed and treated as a formality [54]. Conversely, Bailey et al. [20] found that reducing skill demands of participants can produce broader participation and improve the input received through the process.

\subsubsection{Misalignment between the Public Participation Process and Participants' Sustainability Literacy}

While public participation is an assumed process in sustainability science, large segments of the public are not familiar or do not agree with sustainability norms and principles. When the public participation process does not align with participants' sustainability literacy the gap in knowledge and attitudes about sustainability between experts and stakeholders can be quite large. Also, in some parts of the United States, a sustainability agenda can be met with distrust. Infusing sustainability outcomes into participatory process outputs may require significant capacity building at the front end of the process or experts would have to insert their own perspectives post-process, reducing the credibility of outputs as public-driven. In the case of a participatory process for identifying sustainability indicators in Vancouver, Canada, participants admitted to substantial knowledge gaps regarding sustainability. At first, this lack of sustainability literacy impeded group progress. Through a study circle method, experts built participant capacity and participants successfully developed a robust indicator set [64]. 


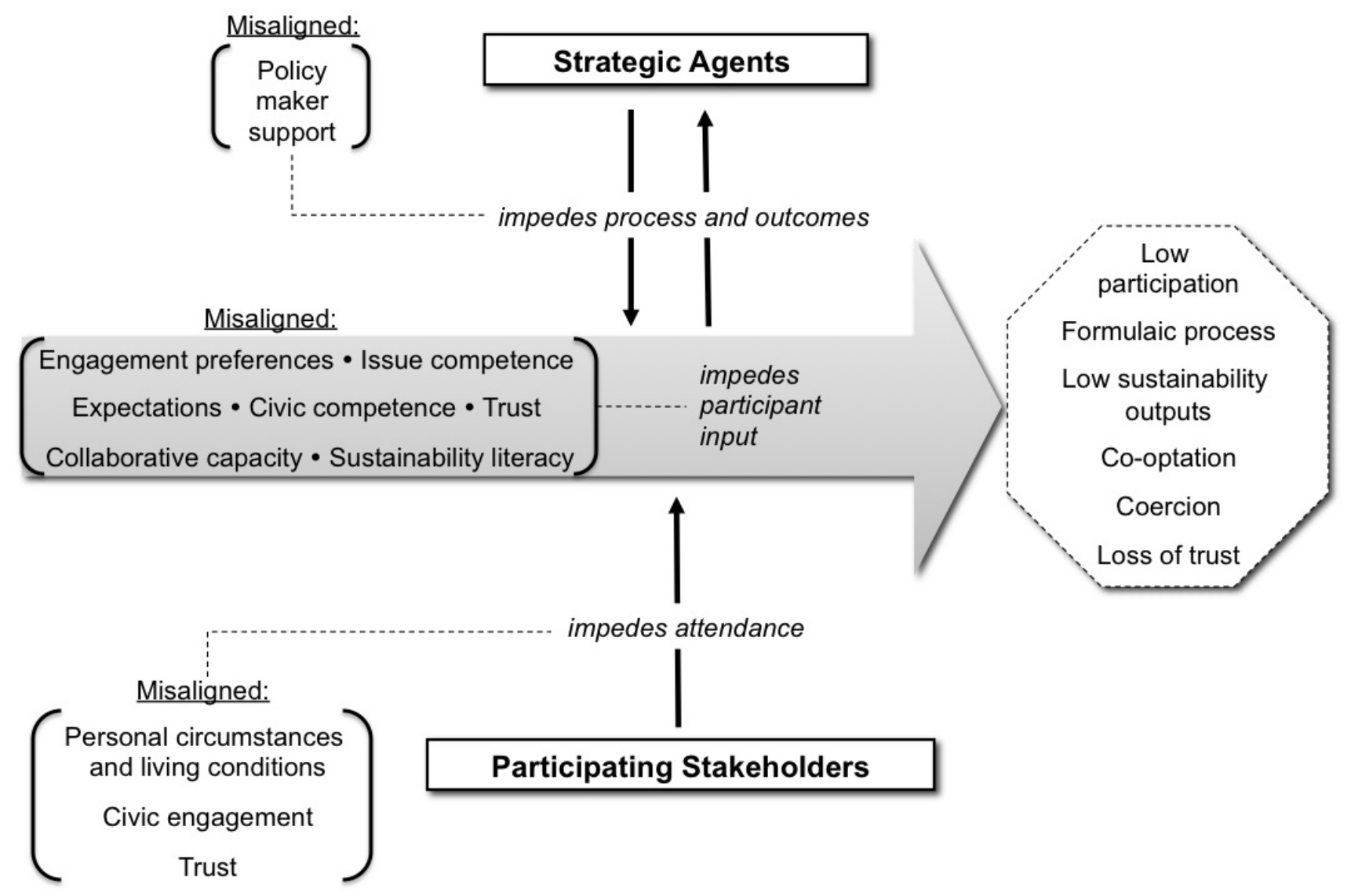

Figure 2. Misalignments mapped onto the public participation process.

\subsubsection{Misalignment between the Public Participation Process and Participants' Issue Competence}

When engaging the public on matters of urban development, experts and planners may be confronted with the challenge of leading participants through discussions of complex urban issues. When the public participation process does not align with participants' issue competence, participants may lack knowledge about urban issues, principles, processes, and planning mechanisms. Cities are complex webs of nested and interrelated systems [75], and not all participants may have the background to meaningfully engage in sophisticated discussions about urban challenges. In the Hackney economic development case discussed above, participants were at first unequipped to engage. One participant admitted that he didn't understand a lot of what was being discussed at meetings, and other participants questioned the level of empowerment when they lacked the capacity to provide meaningful input. Other participants wished for a longer process that would provide more time to acquire the knowledge needed to understand the issues and influence policy. Ultimately, participants required and received capacity building on issues including crime, education, housing, and health [54].
When any of these ten misalignments persist, they can impede the design and implementation of high quality public participation. As described in the introduction to this section, the misalignments manifest at different points during the public participation process. Misalignments may impede the implementation of process outputs, participant attendance at public events, or input (Figure 2).

\section{Conclusions}

Impediments to high-quality public participation may manifest themselves through misalignments between the public participation process and policy maker support, civic engagement, and through participants' personal circumstances and living conditions, engagement preferences, civic competence, collaborative capacity, expectations, trust, sustainability literacy, and issue competence. Designing public participation to fit the local context is a popular recommendation for state-of-the-art urban development projects, but the literature does not provide clear guidance for how this should be achieved. The ten misalignments between the public participation process and the local context identified in this article 
present a contextual frame for public participation process design that avoids major flaws.

Five research streams need to be pursued to consolidate the findings presented here. Future research should

1. Empirically test the misalignments framework in multiple contexts: Although the authors were careful to consider the role that context played in each individual case, it is still difficult to disentangle the findings of a specific case study from the context of the city in which it was set. Therefore, a series of empirical studies are needed to test the misalignments to better understand how they do or do not play out in different settings.

2. Further expand on potential misalignments: These ten misalignments may not present an exhaustive list, and the conceptualization of policy maker support may be broken into smaller, more nuanced issues. The ten misalignments identified in this study present an initial list of common challenges and establishes an agenda to uncover explicit challenges and barriers to public participation in urban development. As this study is a meta-study reliant on the authors of other studies to produce data for analysis, it is possible that important details may have been lost. Therefore, it is critical to continue to study and build out the misalignment framing.

3. Select measurable indicators for each misalignment: A small set of measurable indicators for each misalignment would facilitate the design of well-aligned processes. Indicators would also provide process aspects to measure in evaluations and empirical testing.

4. Identify coping strategies for each misalignment: This study presents the misalignments as common challenges to avoid when planning public participation processes. This research, however, does not provide directives or insights on how to avoid the misalignments.

5. Evaluate public participation processes that attempt to align with the local context: In this study, we contend that the misalignments impede the public participation process, which yields negative consequences for both the process and its outcomes. Substantiating these claims requires empirical evaluation of public participation processes, which is lacking in the literature [44].

By identifying tangible challenges that are common in public participation, this study presents a set of issues around which experts and planners should design public participation processes. While this study raises awareness, it does not provide actionable knowledge for coping with the misalignments. The literature on public participation is mostly descriptive rather than prescriptive and lacks clear directives [44]. Future research will need to study cases that have successfully coped with each misalignment to build an evidence-supported toolset of strategies for aligning participatory processes and contexts for sustainable urban development.

Finally, there is a dearth of evaluative studies of participatory processes in peer-reviewed literature $[5,20]$, and this is partially responsible for the insufficient collection of directives for designing public participation. Defining the misalignments between process and context provides a framework for evaluating public participation processes as we can now ask how well a public participation process is aligned to the local context. Missing from this analysis are potential indicators for measuring each misalignment. By establishing indicators of misalignments and empirically studying real public participation processes, alignment could be measured by collecting data for each indicator. Addressing these misalignments better adapts a public participation process to the local context and presumably result in both a better process and better outcomes. This hypothesis must be tested and validated.

A public participation process that is attuned to the local context is the antithesis to the misalignment framework presented in this paper. Avoiding these misalignments is an aspirational goal and this framework provides a roadmap for achieving an implied vision for high quality public participation in urban development.

\section{References and Notes}

[1] Arnstein SR. A ladder of citizen participation. Journal of the American Institute of planners. 1969;35(4):216-224. doi:10.1080/01944366908977225.

[2] Pateman C. Participation and democratic theory. Cambridge, UK: Cambridge University Press; 1970.

[3] Hawkins CV, Wang X. Sustainable Development Governance. Public Works Management \& Policy. 2011;17(1):7-29. doi:10.1177/1087724x11429045.

[4] Hall JS. Reconsidering the connection between capacity and governance. Public Organization Review. 2002;2(1):23-43. doi:10.1023/A:1016071303640.

[5] Walls J, Rowe G, Frewer L. Stakeholder engagement in food risk management: Evaluation of an iterated workshop approach. Public Understanding of Science. 2011;20(2):241-260. doi:10.1177/0963662509354543.

[6] Evans B, Joas M, Sundback S, Theobald K. Governing local sustainability. Journal of Environmental Planning and Management.
2006;49(6):849-867. doi:10.1080/09640560600946875

[7] Fischer F. Participatory governance as deliberative empowerment: The cultural politics of discursive space. The American Review of Public Administration. 2006;36(1):19-40. doi:10.1177/0275074005282582.

[8] Mimicopoulos MG, Kyj L, Sormani N, Bertucci G, Qian H. Public governance indicators: A literature review. United Nations Organization; 2007. Available from: https://publicadministration.un.org/publications/ content/PDFs/E-Library\%20Archives/2007\%20Public\% 20Governance\%20Indicators_a\%20Literature\%20Review.pdf.

[9] Thomas MA. What do the worldwide governance indicators measure? The European Journal of Development Research. 2010;22(1):31-54. doi:10.1057/ejdr.2009.32.

[10] DiGaetano A, Strom E. Comparative urban governance: An integrated approach. Urban Affairs Review. 2003;38(3):356-395. doi:10.1177/1078087402238806.

[11] Bengston DN, Fletcher JO, Nelson KC. Public policies for managing urban growth and protecting open space: policy instruments and lessons learned in the United States. Landscape and Urban Planning. 
2004:69(2):271-286. doi:10.1016/j.landurbplan.2003.08.007.

[12] van Bueren $E$, ten Heuvelhof $E$. Improving governance arrangements in support of sustainable cities. Environment and Planning B: Planning and Design. 2005;32(1):47-66. doi:10.1068/b31103.

[13] Smedby N, Neij L. Experiences in urban governance for sustainability: the Constructive Dialogue in Swedish municipalities. Journal of Cleaner Production. 2013:50:148-158. doi:10.1016/j.jclepro.2012.11.044.

[14] Agyeman J, Evans T. Toward just sustainability in urban communities: building equity rights with sustainable solutions. The ANNALS of the American Academy of Political and Social Science. 2003;590(1):3553. doi:10.1177/0002716203256565.

[15] Smith R, Wiek A. Achievements and opportunities in initiating governance for urban sustainability. Environment and Planning C: Government and Policy. 2012;30(3):429-447. doi:10.1068/c10158.

[16] Fischer F. Citizen participation and the democratization of policy expertise: From theoretical inquiry to practical cases. Policy Sciences. 1993;26(3):165-187. doi:10.1007/BF00999715.

[17] Zhang Y, Fung T. A model of conflict resolution in public participation GIS for land-use planning. Environment and Planning B: Planning and Design. 2013;40(3):550-568. doi:10.1068/b37033.

[18] Fagotto E, Fung A. Empowered participation in urban governance: the Minneapolis neighborhood revitalization program. International Journal of Urban and Regional Research. 2006;30(3):638-655. doi:10.1111/j.1468-2427.2006.00685.x.

[19] Nevens F, Roorda C. A climate of change: A transition approach for climate neutrality in the city of Ghent (Belgium). Sustainable Cities and Society. 2014;10:112-121. doi:10.1016/j.scs.2013.06.001.

[20] Bailey K, Grossardt T, Ripy J. Toward environmental justice in transportation decision making with structured public involvement. Transportation Research Record: Journal of the Transportation Research Board. 2012;(2320):102-110. doi:10.3141/2320-13.

[21] Sipilä M, Tyrväinen L. Evaluation of collaborative urban forest planning in Helsinki, Finland. Urban Forestry \& Urban Greening. 2005;4(1):1-12. doi:10.1016/j.ufug.2005.06.002.

[22] Blackstock KL, Kelly GJ, Horsey BL. Developing and applying a framework to evaluate participatory research for sustainability. Ecological Economics. 2007;60(4):726-742. doi:10.1016/j.ecolecon.2006.05.014.

[23] Wiek A, Talwar S, O'Shea M, Robinson J. Toward a methodological scheme for capturing societal effects of participatory sustainability research. Research Evaluation. 2014;23(2):117-132. doi:10.1093/reseval/rvt031.

[24] Lang DJ, Wiek A, Bergmann M, Stauffacher M, Martens P, Moll P, et al. Transdisciplinary research in sustainability science: practice, principles, and challenges. Sustainability Science. 2012;7(1):25-43. doi:10.1007/s11625-011-0149-x.

[25] Newman P, Jennings I. Cities as sustainable ecosystems: principles and practices. Washington, DC, USA: Island Press; 2012.

[26] Innes JE, Booher DE. Reframing public participation: strategies for the 21st century. Planning Theory \& Practice. 2004;5(4):419-436. doi: $10.1080 / 1464935042000293170$.

[27] Fung A, Wright EO. Deepening democracy: innovations in empowered participatory governance. Politics \& Society. $2001 ; 29(1): 5-41$. doi:10.1177/0032329201029001002.

[28] De Sousa C. Greening the Industrial District: Transforming Milwaukee's Menomonee Valley from a Blighted Brownfield into a Sustainable Place to Work and Play. In: Sustainability in America's Cities. Springer; 2011. pp. 45-67.

[29] Mandarano L. Clean waters, clean city: sustainable storm water management in Philadelphia. In: Sustainability in America's Cities. Springer; 2011. pp. 157-179.

[30] Koontz TM. Collaboration for sustainability? A framework for analyzing government impacts in collaborative-environmental management. Sustainability: Science, Practice, \& Policy. 2006;2(1). Available from: https://sspp.proquest.com/collaboration-for-sustainability3a15b340d555.

[31] Chaskin R, Khare A, Joseph M. Participation, deliberation, and decision making: The dynamics of inclusion and exclusion in mixedincome developments. Urban Affairs Review. 2012;48(6):863-906. doi:10.1177/1078087412450151.

[32] Cuthill M. Exploratory research: citizen participation, local govern- ment and sustainable development in Australia. Sustainable Development. 2002;10(2):79-89. doi:10.1002/sd.185.

[33] Krek A. Rational ignorance of the citizens in public participatory planning. In: 10th symposium on Information-and communication technologies (ICT) in urban planning and spatial development and impacts of ICT on physical space, CORP. vol. 5; 2005. pp. 420.

[34] Connelly S. Looking inside public involvement: how is it made so ineffective and can we change this? Community Development Journal. 2005;41(1):13-24.

[35] Heiley J. Beyond the formulaic: Process and practice in South Asian NGOs: In: Cooke B, Kothari U, eds. Participation: The New Tyranny New York, NY, USA: Zed Books; 2001

[36] Cooke B. The social psychological limits of participation. 2001;

[37] Council NR, et al. Public participation in environmental assessment and decision making. Washington, DC, USA: National Academies Press; 2008.

[38] Von Korff Y, d'Aquino P, Daniell KA, Bijlsma R. Designing Participation Processes for Water Management and Beyond. Synthesis, part of a special feature on implementing participatory water management: recent advances in theory, practice and evaluation. Ecology and Society. 2010;15(1). Available from: https: //www.ecologyandsociety.org/vol15/iss3/art1/.

[39] Bryson JM, Quick KS, Slotterback CS, Crosby BC. Designing public participation processes. Public Administration Review. 2013;73(1):23-34. doi:10.1111/j.1540-6210.2012.02678.x.

[40] DeCaro D, Stokes M. Public participation and institutional fit: a social-psychological perspective. Ecology and Society. 2013;18(4). doi:10.5751/ES-05837-180440.

[41] Wiek A, Kay B, Cohen M, Golub A. Public participation for sustainable urban development-conceptual framework, evaluative scheme, and case studies. Arizona State University; 2014.

[42] Krütli P, Stauffacher M, Flüeler T, Scholz RW. Functional-dynamic public participation in technological decision-making: site selection processes of nuclear waste repositories. Journal of Risk Research. 2010;13(7):861-875. doi:10.1080/13669871003703252.

[43] Cornwall A. Spaces for transformation? Reflections on issues of power and difference in participation in development. Participation: from tyranny to transformation. 2004;pp. 75-91.

[44] Shipley R, Utz S. Making it count: A review of the value and techniques for public consultation. CPL bibliography. 2012;27(1):22-42. doi:10.1177/0885412211413133.

[45] Friedmann J. Planning in the public domain: From knowledge to action. Princeton, NJ, USA: Princeton University Press; 1987.

[46] Hickey S, Mohan G. Participation-from tyranny to transformation? Exploring new approaches to participation in development. New Yoerk, NY, USA: Zed books; 2004.

[47] Voogd H, Woltjer J. The communicative ideology in spatial planning: some critical reflections based on the Dutch experience. Environment and Planning B: Planning and design. 1999;26(6):835-854 doi:10.1068/b260835.

[48] Abelson J, Forest PG, Eyles J, Smith P, Martin E, Gauvin FP. Deliberations about deliberative methods: issues in the design and evaluation of public participation processes. Social Science \& Medicine. 2003;57(2):239-251. doi:10.1016/S0277-9536(02)00343-X.

[49] King CS, Feltey KM, Susel BO. The question of participation: Toward authentic public participation in public administration. Public Administration Review. 1998;pp. 317-326. doi:10.2307/977561.

[50] Cohen N. Technical assistance for citizen participation: a case study of New York City's environmental planning process. The American Review of Public Administration. 1995;25(2):119-135. doi:10.1177/027507409502500202.

[51] Chipeniuk R. Public explanations for environmental degradation in a sustainable land use planning exercise. Landscape and Urban Planning. 1999;45(2):93-106. doi:0.1016/S0169-2046(99)00029-8.

[52] Poindexter GC. Who Gets the Final No-Tenant Participation in Public Housing Redevelopment. Cornell Journal of Law and Public Pulicy. 1999;9:659. Available from: http://scholarship.law.cornell.edu/cjlpp/ vol9/iss3/2

[53] Eversole R. Managing the pitfalls of participatory development: some insight from Australia. World development. 2003;31(5):781-795. doi:10.1016/S0305-750X(03)00018-4.

[54] Perrons D, Skyers S. Empowerment through participation? Concep- 
tual explorations and a case study. International Journal of Urban and Regional Research. 2003;27(2):265-285. doi:10.1111/14682427.00447.

[55] Barnes M, Knops A, Newman J, Sullivan H. Recent research: The micro-politics of deliberation: Case studies in public participation. Contemporary Politics. 2004;10(2):93-110. doi:10.1080/1356977042000278756.

[56] Irvin RA, Stansbury J. Citizen participation in decision making: Is it worth the effort? Public Administration Review. 2004;64(1):55-65. doi:10.1111/j.1540-6210.2004.00346.x.

[57] Lahiri-Dutt K. 'I plan, you participate': A southern view of community participation in urban Australia. Community Development Journal. 2004;39(1):13-27. doi:10.1093/cdj/39.1.13.

[58] Shipley R, Feick R, Hall B, Earley R. Evaluating municipal visioning. Planning Practice and Research. 2004;19(2):195-210. doi:10.1080/0269745042000284412.

[59] Bickerstaff K, Walker G. Shared visions, unholy alliances: power, governance and deliberative processes in local transport planning. Urban Studies. 2005;42(12):2123-2144. doi:10.1080/00420980500332098.

[60] Yang K. Public administrators' trust in citizens: A missing link in citizen involvement efforts. Public Administration Review. 2005;65(3):273285. doi:10.1111/j.1540-6210.2005.00453.x.

[61] Janse G, Konijnendijk CC. Communication between science, policy and citizens in public participation in urban forestry-Experiences from the Neighbourwoods project. Urban Forestry \& Urban Greening. 2007;6(1):23-40. doi:10.1016/j.ufug.2006.09.005.

[62] Lee CW. Is there a place for private conversation in public dialogue? Comparing stakeholder assessments of informal communication in collaborative regional planning. American Journal of Sociology. 2007;113(1):41-96. doi:10.1086/517898.

[63] Sylvestre J, Cousins JB, Sundar P, Aubry T, Hinsperger V. Engaging stakeholders in the planning of a collaborative multiagency evaluation: The HousingPlus Collaborative Communities Project. Studies in Educational Evaluation. 2008;34(4):212-217. doi:10.1016/j.stueduc.2008.10.005.

[64] Holden M. Public participation and local sustainability: Questioning a common agenda in urban governance. International Journal of Urban and Regional Research. 2011;35(2):312-329. doi:10.1111/j.14682427.2010.00957.x
[65] Sheppard SR, Shaw A, Flanders D, Burch S, Wiek A, Carmichael J, et al. Future visioning of local climate change: a framework for community engagement and planning with scenarios and visualisation Futures. 2011;43(4):400-412. doi:10.1016/j.futures.2011.01.009.

[66] Leino $\mathrm{H}$, Laine $\mathrm{M}$. Do matters of concern matter? Bringing issues back to participation. Planning Theory. 2012;11(1):89-103. doi:10.1177/1473095211417595.

[67] Walker PE, Shannon PT. Participatory governance: towards a strategic model. Community Development Journal. 2011;46(suppl_2):ii63ii82. doi:10.1093/cdj/bsr011.

[68] Mouffe C. Deliberative democracy or agonistic pluralism. Vienna, Austria: Institute of Advanced Studies; 2000. Available from: https://www.ihs.ac.at/publications/pol/pw_72.pdf.

[69] Abers RN. Reflections on what makes empowered participatory governance happen. In: Fung A, Wright EO, editors. Deepening democracy: Institutional innovations in empowered participatory governance. London, UK: Verso; 2003. pp. 200-207.

[70] Goldfrank B. Participatory budgeting and urban sustainability. In: Institutional and Social Innovation for Sustainable Urban Development. New York, NY, USA: Routledge; 2013. pp. 57-71.

[71] Holden M, Owens C, Mochrie C. Lessons from a community-based process in regional sustainability indicator selection: The case of the Regional Vancouver Urban Observatory. In: Sirgy JM, Philips R, Rahtz DR, editors. Community Quality-of-Life Indicators: Best Cases IV. Springer; 2009. pp. 59-80.

[72] Putnam RD. Bowling alone: America's declining social capital. Springer; 2000. pp. 223-234.

[73] Bailey K, Grossardt T. Toward structured public involvement: justice, geography and collaborative geospatial/geovisual decision support systems. Annals of the Association of American Geographers. 2010;100(1):57-86. doi:10.1080/00045600903364259.

[74] Kwaku Kyem PA. Of intractable conflicts and participatory GIS applications: The search for consensus amidst competing claims and institutional demands. Annals of the Association of American Geographers. 2004;94(1):37-57. doi:10.1111/j.14678306.2004.09401003.x.

[75] Samet $\mathrm{RH}$. Complexity, the science of cities and long-range futures. Futures. 2013;47:49-58. doi:10.1016/j.futures.2013.01.006. 